\title{
ARTYKUŁY
}

Klio. Czasopismo poświęcone dziejom Polski i powszechnym

PL ISSN 1643-8191, t. 30 (3)/2014, s. 3-18

\author{
(c) $(1) \Theta$ \\ http://dx.doi.org/10.12775/KLIO.2014.040 \\ Szymon Olszaniec, Marcin PaWlak, \\ PrZEMYSŁaW Wojciechowski \\ (Toruń)
}

\section{Prof. Maria Jaczynowska - wybitna badaczka świata starożytnego}

WX 2013 roku minęło pięć lat od śmierci Prof. Marii Jaczynowskiej, wyW bitnej badaczki starożytności, związanej z naszym Uniwersytetem, twórczyni i wieloletniego kierownika Zakładu Historii Starożytnej Instytutu Historii i Archiwistyki UMK. Z tej okazji chcieliśmy przypomnieć Jej sylwetkę oraz przybliżyć, choć fragmentarycznie, najważniejsze dokonania z szerokiego spektrum Jej zainteresowań naukowych.

\section{Życie i działalność Prof. Marii Jaczynowskiej}

Maria Jaczynowska przyszła na świat 17 lutego 1928 roku w Warszawie, w rodzinie Jana, nauczyciela geografii w warszawskim Gimnazjum Górskiego, oraz Marii, urzędniczki Izby Przemysłowo-Handlowej przy Ministerstwie Przemysłu i Handlu. Swoją drogę przez życie z historią starożytną zaczęła bardzo wcześnie. Interesowała się bowiem tą dziedziną już w trakcie edukacji w Gimnazjum J. Kowalczykówny i J. Jawurkówny 
w Warszawie. Potem przyszła wojna, tajne komplety, czynny udział w Szarych Szeregach i w powstaniu warszawskim, jednakże po zakończeniu tego etapu życia, wybierając ośrodek akademicki, w którym planowała studiować, poszukiwała już dobrych warunków do wyspecjalizowania się w ulubionej dyscyplinie. Ostatecznie studia historyczne rozpoczęła na Uniwersytecie Łódzkim (1946-1948), gdzie swoje seminarium prowadził Prof. Józef Wolski, a następnie w latach 1948-1951 kontynuowała je na Uniwersytecie Warszawskim. Tutaj pod kierownictwem papirologa, Prof. Jerzego Manteuffla, przygotowała pracę magisterską nt. Rozwój rzemiosta w nomie Oxyrynchos, opublikowaną w „Meandrze” w 1951 roku.

Zaraz po zakończeniu studiów objęła stanowisko starszego asystenta w Instytucie Historycznym UW, a w 1955 roku porzuciła Warszawę i związała się z UMK. W 1958 roku, już pracując w Toruniu, Maria Jaczynowska obroniła na Uniwersytecie Warszawskim pracę doktorską napisaną pod kierownictwem Prof. Izy Bieżuńskiej-Małowist nt. Sytuacja ekonomiczna nobilitas $w$ okresie schytku republiki rzymskiej i została adiunktem. Szybko też pokonała kolejny szczebel kariery naukowej. Przygotowując rozprawę habilitacyjną, diametralnie zmieniła obszar i tematykę badawczą. Podjęcie problematyki elit pryncypatu wymagało od Niej dalszego poszerzania warsztatu i pogłębionych studiów epigraficznych. W napisaniu pracy pomogło Jej roczne stypendium w Paryżu, odbyte w latach 1961-1962, gdzie studiowała pod okiem wybitnego epigrafika H.-G. Pflauma. Podczas pobytu we Francji zebrała materiał, który stał się podstawą do rozprawy habilitacyjnej Collegia iuvenum. Rola historyczna i dziatalność organizacji mtodzieży rzymskiej w okresie cesarstwa. Po uzyskaniu w 1965 roku tytułu doktora habilitowanego objęła kierownictwo Zakładu Historii Starożytnej, którą to funkcję sprawowała ponad 33 lata, aż do emerytury w roku 1998. W 1978 roku, nakładem Wydawnictwa Ossolineum, ukazała się francuska wersja rozprawy habilitacyjnej: Les associations de la jeunesse romaine sous le Haut-Empire. Jest to publikacja cytowana przez zachodnich uczonych także współcześnie, do niedawna zaś była jedyną monografią z tej tematyki. Maria Jaczynowska brała też bardzo aktywny udział w międzynarodowym życiu naukowym, kongresach Eirene, grupujących uczonych z Zachodu i Wschodu oraz międzynarodowych sympozjach epigrafików (AIEGL: Assocation Internationale d'Epigraphie Grecque et Latine), wygłosiła też 
szereg wykładów na uniwersytetach w Padwie, Bolonii, Pawii, Florencji oraz Besançon, Dijon i na Sorbonie. Opublikowała również wiele artykułów w językach kongresowych, ogłoszonych m.in. w tak renomowanych periodykach jak: „Historia. Zeitschrift für Alte Geschichte”, „Athenaeum” czy „Dialogues d'histoire ancienne”.

Szczególne miejsce w dorobku Prof. Jaczynowskiej zajmuje obszerny, syntetyczny artykuł poświecony kultowi Herkulesa, zamieszczony w roku 1981 w słynnej serii wydawniczej „Aufstieg und Niedergang der Römischen Welt” (t. 17/2) wydawanej przez wydawnictwo Walter de Gruyter. Podobnie jak monografia poświęcona iuvenes, tak i wspomniany artykuł, jest do dziś często cytowany przez zachodnich badaczy.

Tematyka religijna zdominowała późniejsze dokonania naukowe Marii Jaczynowskiej. W pewnym sensie ich zwieńczeniem była publikacja w roku 1987 Wydawnictwa PWN syntezy Religie świata rzymskiego, która podkreślała Jej pozycję w Polsce jako czołowego badacza tej tematyki. Książka ta przyniosła Jej profesurę „belwederską”, warto też podkreślić, że do dzisiaj pozostaje ona ważnym opracowaniem funkcjonującym w polskiej literaturze przedmiotu.

Maria Jaczynowska aktywnie włączała się w życie macierzystego Instytutu Historii, jak również całego Uniwersytetu. Jak już wspomnieliśmy, przez wiele lat była kierownikiem Zakładu Historii Starożytnej, a w latach 1973-1975 piastowała funkcję dyrektora Instytutu Historii i Archiwistyki UMK. W okresie swojej największej aktywności zapraszała na wykłady do Torunia wybitnych gości, zarówno z Polski, jak i z zagranicy, w roku 1985 zaś była promotorem nadania tytułu doktora honoris causa naszego uniwersytetu znakomitemu epigrafikowi z Uniwersytetu w Padwie, Prof. Franco Sartoriemu.

Uzyskawszy habilitację, Maria Jaczynowska otworzyła seminarium magisterskie, które traktowała jako „kuźnię” swoich następców. Prof. Jaczynowska wypromowała ośmiu doktorów (Józef Zając, Janusz Tondel, Mariusz Ziółkowski, Danuta Musiał, Szymon Olszaniec, Ryszard Sajkowski [związany z Uniwersytetem Warmińsko-Mazurskim w Olsztynie], Livio Zerbini [Università degli Studi di Ferrara, Włochy], Marcin Pawlak oraz dwóch doktorów habilitowanych (Józef Zając i Danuta Musiał), dwóch dalszych zaś: Szymon Olszaniec i Marcin Pawlak uzyskało ten tytuł już po Jej 
śmierci. Absolwentami prowadzonego przez Prof. Jaczynowską seminarium magisterskiego byli też: prof. UMK, dr hab. Przemysław Wojciechowski oraz dr hab. Katarzyna Maksymiuk, aktualnie pracownik Uniwersytetu Przyrodniczo-Humanistycznego w Siedlcach.

Prof. Jaczynowska zajmowała się również popularyzowaniem historii starożytnej w różnych kręgach odbiorców. Jeszcze pod koniec lat sześćdziesiątych minionego stulecia wraz z Anną Mączakową i Witoldem Tylochem napisała Historie starożytna, czyli popularne „trojaczki”, gdzie była odpowiedzialna za historię Rzymu i redakcję całości. Wkrótce też podjęła się opracowania samodzielnego skryptu uniwersyteckiego, który okazał się, wstępem do szerszej wersji przeznaczonej dla Wydawnictwa PWN. Podręcznik Historia starożytnego Rzymu doczekał się aż siedmiu wydań i wychowały się na nim całe generacje polskich studentów historii i starożytników. Po kilkunastu latach Prof. Jaczynowska podjęła się po raz kolejny napisania samodzielnie syntezy dziejów Rzymu. Podręcznik zatytułowany Dzieje Imperium Romanum Wydawnictwo PWN opublikowało w roku 1995. Łączył on najlepsze cechy pisarstwa historycznego - był napisany ze swadą, a przy tym reprezentował zaktualizowany stan badań, przynosił też m.in. pierwszą polską syntezę historii Rzymu w okresie późnego cesarstwa liczącą blisko 160 stron.

Za sukcesy zarówno naukowe, jak i popularyzatorskie była wielokrotnie nagradzana, w tym wysokimi nagrodami ministerialnymi. Niestety już po śmierci Prof. Jaczynowskiej nakładem wydawnictwa „Trio” ukazał się kolejny podręcznik historii Rzymu, napisany wspólnie z dr Marcinem Pawlakiem, Starożytny Rzym, stanowiący podsumowanie Jej drogi jako dydaktyka i popularyzatora historii.

\section{Prof. Maria Jaczynowska i epigrafika}

Prof. Jaczynowska była jednym z pierwszych historyków starożytności w Polsce, którzy dostrzegli możliwości, jakie badaczowi antyku stwarzają źródła epigraficzne. Co prawda początki zainteresowania rzymskimi napisami sięgają w Polsce przynajmniej czasów Stanisława Augusta Poniatowskiego, który zgromadził kolekcję złożoną z ponad dwudziestu 
inskrypcji łacińskich, jednak trudno w tym wypadku mówić o ich naukowym wykorzystaniu. Aż do lat sześćdziesiątych ubiegłego wieku epigrafika była w Polsce domeną kolekcjonerów i podróżujących po Europie erudytów. Dopiero rozpoczęcie polskich wykopalisk w Novae oraz publikacja wyników badań Tadeusza Zawadzkiego, Tadeusza Kotuli, Jerzego Kolendy i właśnie Marii Jaczynowskiej dały bardzo silny impuls do rozwoju tej dziedziny nauki w Polsce ${ }^{1}$. W ciągu zaledwie trzech lat wydano kilka wybitnych monografii, których bazę źródłową stanowił materiał epigraficzny. Studia dotyczące zgromadzeń prowincjonalnych w Afryce, których autorem jest T. Kotula (1965), opracowanie J. Kolendy poświęcone kolonatowi w rzymskiej Afryce (1962) oraz książka M. Jaczynowskiej na temat stowarzyszeń rzymskiej młodzieży w okresie pryncypatu (1964) zapewniły ich autorom trwałe miejsce nie tylko w polskiej, lecz także światowej historiografii. Książka M. Jaczynowskiej pt. Collegia iuvenum. Rola historyczna i dziatalność organizacji mtodzieży rzymskiej $w$ okresie wczesnego cesarstwa, mimo upływu ponad półwiecza od jej publikacji, jest do dziś cytowana przez badaczy zajmujących się życiem korporacyjnym w Imperium Romanum. Do wyników badań M. Jaczynowskiej odwołują się autorzy wszystkich najważniejszych studiów dotyczących różnych aspektów rzymskiego il fenomeno associativo wydanych w ciągu ostatniego pięćdziesięciolecia ${ }^{2}$. Niezależnie od typu publikacji, celów i metod badawczych stosowanych przez poszczególnych historyków, w momencie, gdy w ich wywodach pojawiają się collegia iuvenum, nie pozostaje im nic innego niż powołać się na ustalenia, jakie w tym zakresie poczyniła M. Jaczynowska. Rodzi się pytanie o to, co sprawia, że mimo wyraźnego wzrostu zainteresowania rzymskim korpora-

${ }^{1}$ Za pierwszy sygnał naukowego zainteresowania antycznymi napisami można uznać opublikowany przez Annę Sadurską w 1953 r. katalog inskrypcji łacińskich znajdujących się w Muzeum Narodowym w Warszawie (Inscriptions latines et monuments funéraires romains au Musée National de Varsovie, Warszawa 1953).

2 Tylko w ostatnich kilku latach na wyniki badań M. Jaczynowskiej powołują się m.in.: N. Tran, Les membres des associations romaines: le rang social des collegiati en Italie et en Gaules, sous le haut-empire. Rome 2006;F. Diosono, Collegia. Le associazioni professionali nel mondo romano, Roma 2007; J. Liu, Collegia centonariorum: the guilds of textile dealers in the Roman West, Leiden-Boston 2009; D. Rohde, Zwischen Individum und Stadtgemeinde. Die Integration von collegia in Haffenstaeden, Mainz 2012. 
cjonizmem w ostatnich latach, nie tylko nie zakwestionowano wyników badań prof. Jaczynowskiej, ale nie podjęto nawet próby nowego opracowania problematyki związanej z rzymskimi kolegiami młodzieży. Wydaje się, że tym, co decyduje o aktualności książki M. Jaczynowskiej jest gruntowność, z jaką analizuje ona niezwykle skrupulatnie zgromadzony materiał źródłowy. Opracowany przez nią korpus epigraficzny obejmuje ponad 220 napisów pochodzących z całego obszaru cesarstwa rzymskiego. Tak obszerny materiał źródłowy pozwolił na sformułowanie wielu istotnych wniosków dotyczących zarówno funkcjonowania stowarzyszeń młodzieży rzymskiej, jak i struktury społecznej tych organizacji. Wnioski te pozostają aktualne również dlatego, że ich autorka nie uległa dominującej w latach sześćdziesiątych ubiegłego wieku tendencji do postrzegania rzymskiego korporacjonizmu przez pryzmat walki o poprawę sytuacji życiowej tzw. „małych ludzi”, która w skrajnych przypadkach była traktowana jako jeden z przejawów walki klasowej. Nieprzypadkowo problematyka korporacyjna stała się wówczas jednym z ulubionych tematów badawczych historyków wywodzących się z krajów „bloku wschodniego” i ich marksizujących kolegów z Europy zachodniej. Tak samo jak nieprzypadkowe było zainteresowanie rzymskimi korporacjami w faszystowskich Włoszech. Maria Jaczynowska całkowicie oderwała swe studia od kontekstu współczesnej dyskusji politycznej. Być może stało się to za sprawą współpracy z H.-G. Pflaumem podczas pobytu w Paryżu w latach 1961-1962. Studia pod okiem tego wybitnego epigrafika pozostawiły swe piętno na dalszej karierze naukowej M. Jaczynowskiej, wskazując kierunek i metodę badawczą, którą badaczka konsekwentnie rozwijała w kolejnych latach i publikacjach. Być może to właśnie pobyt w Paryżu spowodował, że w dalszej karierze naukowej M. Jaczynowskiej bardzo wyraźne było dążenie do udostępniania wyników własnych badań jak najszerszemu gronu odbiorców. Publikowane przede wszystkim po francusku, ale także w innych językach kongresowych, monografie i artykuły znajdowały czytelników w środowisku historyków starożytności w całej Europie. Dotyczy to także, a może przede wszystkim, jej studiów epigraficznych. Poza przełożoną na język francuski rozprawą poświęconą kolegiom iuvenum, w latach siedemdziesiątych i osiemdziesiątych regularnie ukazywały się kolejne publikacje naukowe, w których coraz wyraźniej dominującą rolę zaczęła odgrywać tematyka religijna. W centrum 
zainteresowania prof. Jaczynowskiej znalazł się wówczas materiał epigraficzny dokumentujący różne przejawy życia religijnego w świecie rzymskim. Szczególnie dużo uwagi poświęciła ona badaniom nad kultem Herkulesa, których zwieńczeniem był zbiór studiów dotyczących różnych aspektów tego kultu, od jego roli w ideologii cesarskiej, poprzez jego lokalne przejawy, aż po przemiany, jakim kult ten podlegał w okresie późnego antyku3 Tekst ten, opublikowany w 1981 roku w wydawanej w Berlinie prestiżowej serii Aufstieg und Niedergang der Römischen Welt, stał się jedną z klasycznych publikacji w zakresie badań nad rzymską religijnością. Maria Jaczynowska wykorzystała w tej publikacji wyniki studiów nad klasycznymi źródłami literackimi, jak i nad setkami napisów epigraficznych pochodzących z zachodniej części rzymskiego imperium. W podobny sposób powstała książka, która do dziś pozostaje jedyną w polskiej historiografii próbą przedstawienia „rozwoju historycznego religii Imperium Rzymskiego" ${ }^{4}$. Znaczenie tej publikacji polega nie tylko na tym, że wypełnia ona jedną z wielu luk w polskich badaniach nad antykiem, lecz również - a może przede wszystkim - na tym, że dzięki niej w naszym dyskursie naukowym pojawiły się niemal nieobecne wcześniej poglądy historyków od dawna uznawanych za klasyków w dziedzinie badań nad rzymską religijnością. Nawet jeśli wiele opinii czy interpretacji prezentowanych przez takich uczonych, jak: G. Wissowa, G. Dumézil czy F. Cumont zweryfikowały późniejsze badania, trudno sobie bez nich wyobrazić dyskusję o życiu religijnym imperium rzymskiego. Z epigraficznego punktu widzenia szczególnie interesujące są te rozdziały Religii świata rzymskiego, które zostały poświęcone wierzeniom ludów prowincji. Profesor Jaczynowska rekonstruuje owe wierzenia przede wszystkim na podstawie analizy świadectw epigraficznych. Również tzw. kulty orientalne i w znacznej mierze kult cesarski, które także są przedmiotem Jej badań, pozostawiły po sobie ślady głównie w formie inskrypcji. Zastosowana przez Prof. Jaczynowską metoda badawcza, polegająca na połączeniu analizy danych pochodzących z przekazów literackich, źródeł

${ }^{3}$ Le culte de l'Hercule romain au temps du Haut-Empire, ANRW II 17, 2, 1981, 631-661.

${ }^{4}$ Sformułowanie użyte przez M. Jaczynowską we „Wstępie” do Religii świata rzymskiego, Warszawa 1987. 
epigraficznych i wykopalisk, dziś uważana za standard w badaniach nad kultami religijnymi świata rzymskiego, w momencie publikacji Jej książki torowała sobie dopiero drogę w polskiej historiografii 5 .

Przegląd dokonań prof. Jaczynowskiej na polu epigrafiki pokazuje, że przedmiotem jej zainteresowania były nie tyle same inskrypcje, ile ludzie, bogowie, instytucje czy zjawiska, które pojawiały się w tekstach epigraficznych. W tym sensie M. Jaczynowska nie była klasycznym epigrafikiem. Była jednym z tych historyków starożytności, którzy w łacińskich inskrypcjach pochodzących z obszaru całego Imperium Romanum poszukiwali świadectw, argumentów, przykładów potwierdzających lub negujących stawiane przezeń bądź przez innych badaczy tezy. Jej studia nad kolegiami iuvenum oraz kultem Herkulesa w zachodniej części imperium rzymskiego stały się wzorem i inspiracją dla wielu historyków zajmujących się badaniami dziejów starożytnego Rzymu. Z kolei badania nad rzymskimi rozdawnictwami prywatnymi prowadzone przez S. Mrozka ${ }^{6}$, którego początki kariery związane są z kierowanym przez M. Jaczynowską toruńskim Zakładem Historii Starożytnej, czy publikacje z zakresu antycznej onomastyki autorstwa Józefa Zająca - pierwszego ucznia prof. Jaczynowskiej i jednego z najwybitniejszych znawców dziejów północnej Italii ${ }^{7}$ - to najlepsze, ale nie jedyne ${ }^{8}$, przykłady wpływu, jaki na rozwój polskiej epigrafiki miała M. Jaczynowska.

5 Pod kierunkiem prof. Jaczynowskiej powstały trzy rozprawy doktorskie dotyczące tematyki religijnej, których autorzy odwołują się do tej metody, zob.: J. Zając, Kulty religijne spoteczeństwa rzymskiej prowincji Noricum w okresie wczesnego cesarstwa (1975); M. Ziółkowski, Kulty religijne żotnierzy rzymskiej prowincji Brytanii w okresie wczesnego cesarstwa (1981) oraz D. Musiał, Le développement du culte d'Esculape au monde romain, Toruń 1993. W tym samym nurcie mieści się rozprawa doktorska P. Wojciechowskiego napisana pod kierunkiem J. Zająca, a poświęcona lokalnym kultom rzymskiej Akwilei (Beleno Augusto sacrum. Celtyckie i weneckie bóstwa rzymskiej Akwilei, Toruń 2000).

${ }^{6}$ S. Mrozek, Prywatne rozdawnictwa pieniędzy i żywności $w$ miastach Italii $w$ okresie Wczesnego Cesarstwa, Warszawa-Poznań 1973.

7 J. Zając, Od Wenetów do Rzymian. Studium epigraficzno-antroponomastyczne (I w. p.n.e.-I w. n.e.), Toruń 1991; idem, Wyzwoleńcy w antycznej Brixii: studium prozopograficzne (I-1. pot. III w. n.e.), Toruń 2000.

${ }^{8}$ Ograniczając się jedynie do kręgu uczniów i współpracowników M. Jaczynowskiej, z łatwością można wskazać kolejne studia, dla których podstawową bazę źródłową sta- 


\section{Prof. Maria Jaczynowska jako autorka podręczników}

Maria Jaczynowska jako autorka podręczników zadebiutowała w 1969 roku. To właśnie wtedy Wydawnictwa Szkolne i Pedagogiczne opublikowały wspomniany już, przygotowany pod jej redakcją, podręcznik zatytułowany Historia Starożytna. Zgodnie z tytułem było to jednotomowe opracowanie dziejów zarówno starożytnego Wschodu, Grecji, jak i Rzymu. Autorami, obok M. Jaczynowskiej, która napisała część dotyczącą Rzymu, byli Anna Mączakowa i Witold Tyloch. Warto przypomnieć, że omawiana publikacja nie była skierowana bezpośrednio do studentów. Była ona raczej pomyślana jako książka pomocnicza adresowana do nauczycieli. Część autorska M. Jaczynowskiej liczy ponad 150 stron i jest chronologicznym omówieniem dziejów Rzymu od powstania samego miasta aż do upadku zachodniego cesarstwa rzymskiego. Autorka koncentrowała się przede wszystkim na bardzo klarownym prezentowaniu treści, z rzadka tylko wprowadzała czytelnika w dyskusje naukowe (czyniła tak, gdy przedstawiała szczególnie kontrowersyjne zagadnienia). Zainteresowany czytelnik mógł jednak sięgnąć do bibliografii, w której podano zarówno opracowania - głównie polskich autorów lub tłumaczonych na język polski - oraz przekłady z literatury łacińskiej.

Już rok po ukazaniu się przywołanej wyżej pracy, Wydawnictwo UMK opublikowało skrypt autorstwa M. Jaczynowskiej zatytułowany Historia starożytnego Rzymu. Zarys syntetyczny dla studentów I roku historii (wyd. 1 - 1970, wyd. 2 - 1971). Autorka odeszła zatem od koncepcji podręcznika obejmującego całą starożytność na rzecz osobnego podręcznika tylko do historii Rzymu. Od razu wypada dodać, że takiemu rozwiązaniu pozostała wierna przez blisko trzydzieści kolejnych lat. Już we „Wstępie”

nowiły rzymskie inskrypcje. Do przytoczonych wcześniej rozpraw doktorskich J. Zająca, M. Ziółkowskiego, D. Musiał i P. Wojciechowskiego dodać należy pracę J. Tondela o Augustales w prowincjach naddunajskich oraz książkę D. Musiał, Antyczne korzenie chrześcijaństwa (Warszawa 2001), w której autorka powraca do rozważań nad rzymską religijnością. Dla P. Wojciechowskiego próba weryfikacji i uzupełnienia ustaleń M. Jaczynowskiej dotyczących społecznych aspektów kultu Herkulesa w Rzymie stała się głównym impulsem do podjęcia pracy nad monografią Czciciele Herkulesa w Rzymie. Studium epigraficzno-antroponomastyczne (Toruń 2005). 
do skryptu autorka uprzedzała czytelnika, że jego zadaniem „nie jest pełne przedstawienie historii Rzymu, które mogłoby zastąpić podręcznik uniwersytecki”. Dodawała również, powołując się przy tym na dyskusje toczone w czasie obrad sekcji historii starożytnej X Powszechnego Zjazdu Historyków Polskich (Lublin 9-13 września 1969 r.), że w pełni odpowiadający potrzebom czasów byłby podręcznik trzytomowy napisany przez kilku autorów. Ponieważ jednak prace nad tak pomyślanym podręcznikiem nawet się jeszcze ówcześnie nie zaczęły, dlatego autorka zdecydowała się „przynajmniej w sposób doraźny zapełnić najbardziej dotkliwe luki w zakresie pomocy naukowych dla studentów I roku historii”. Efektem tych starań był właśnie omawiany skrypt. Prof. Jaczynowska nie kryła, że jej celem jest dostarczenie pracy, która mogłaby, jeśli nawet nie zastąpić, to przynajmniej uzupełnić, wykorzystywany wcześniej w dydaktyce uniwersyteckiej podręcznik Nikołaja A. Maszkina zatytułowany Historia starożytnego Rzymu. Polskie wydanie tego podręcznika ukazało się 20 lat przed publikacją omawianego skryptu i siłą rzeczy nie mogło uwzględniać nowszych zdobyczy naukowych, które spowodowały zmiany w przedstawianiu wielu problemów z dziejów Rzymu. M. Jaczynowska zwracała ponadto uwagę, że w podręczniku Maszkina materiał jest bardzo nierównomiernie rozłożony (uprzywilejowanie dziejów republiki rzymskiej kosztem cesarstwa), nie ujmuje on ponadto historii Rzymu w sposób problemowy, co mogłoby ułatwić jej zrozumienie. Dodatkowo zwracała uwagę, że Maszkin pisał swą pracę „W okresie stalinowskim, stąd jego „dogmatyczne” przedstawienie niektórych trudnych problemów historii Rzymu - zwłaszcza upadku cesarstwa rzymskiego". Autorka przypomniała wreszcie, że Maszkin uwzględniał przede wszystkim ustalenia nauki radzieckiej, a tymczasem student powinien mieć możliwość zapoznania się z dokonaniami uczonych także z innych krajów, w tym oczywiście z Polski.

Podręcznik Historia starożytnego Rzymu miał w zamierzeniu autorki uzupełnić najbardziej dotkliwe braki i luki w pracy Maszkina. Autorka uprzedzała czytelnika, że skróciła te partie, które jej zdaniem zostały przez Maszkina dobrze opracowane, a jej zamiarem było przedstawienie historii Rzymu w sposób problemowy. Podręcznik składa się z pięciu części poświęconych kolejno Rzymowi królewskiemu i dziejom wczesnej republiki, republice rzymskiej w okresie od początków III w. p.n.e. do schyłku II wie- 
ku p.n.e., dziejom schyłku republiki, wczesnemu cesarstwu rzymskiemu i wreszcie późnemu cesarstwu rzymskiemu. Od razu wypada zaznaczyć, że ostatnia część jest najbardziej skrótowa (21 stron) i obejmuje ogólną charakterystykę dominatu jako systemu politycznego i społeczno-gospodarczego, chrześcijaństwo jako religię państwową, kulturę późnego cesarstwa oraz wędrówkę ludów i upadek cesarstwa zachodniorzymskiego. Zgodnie z zapowiedzią poczynioną we wstępie, że w miarę możliwości będzie starać się zapełniać luki istniejące w pracy Maszkina, najwięcej miejsca M. Jaczynowska poświęciła dziejom wczesnego cesarstwa rzymskiego (87 stron). Już w tym pierwszym samodzielnym podręczniku Marii Jaczynowskiej pojawiają się te wszystkie elementy, które będą występować w jej późniejszych publikacjach o charakterze podręcznikowym.

W latach siedemdziesiątych Maria Jaczynowska podjęła współpracę z Państwowym Wydawnictwem Naukowym. Jej efektem było opublikowanie w 1974 roku podręcznika zatytułowanego Historia Starożytnego Rzymu. W kolejnych latach praca ta doczekała się siedmiu wydań (ostatnie w 1988 roku) i to właśnie dzięki niej prof. Jaczynowska była znana wielu rocznikom studentów historii. Publikację omawianego podręcznika sama autorka uznała za kolejną próbę wypełnienia dotkliwej luki „w zakresie pomocy dydaktycznych dla studentów historii”. Odniosła się przy tym do swych wcześniejszych publikacji podręcznikowych i stwierdziła m.in., że wydany w 1970 roku skrypt Historia starożytnego Rzymu. Zarys syntetyczny dla studentów I roku historii został bardzo szybko wykupiony przez studentów, ponadto miał charakter skrótowego zarysu. Nie kryła jednak, że książka opublikowana przez PWN jest po prostu nową szerszą wersją skryptu toruńskiego. Nowością było umieszczenie w tekście przypisów odsyłających do prac polskich i obcojęzycznych oraz do źródeł antycznych. Przypisy pojawiały się zawsze wtedy, gdy autorka omawiała najbardziej dyskusyjne problemy z dziejów Rzymu. Podręcznik miał chronologiczny układ i był podzielony na sześć części. W porównaniu z wcześniejszymi publikacjami podręcznikowymi w omawianej pracy Maria Jaczynowska położyła nacisk na drobiazgowe przedstawienie przemian ustrojowych w okresie cesarstwa oraz sposobu funkcjonowania aparatu biurokracji cesarskiej. Taki zabieg był niewątpliwie efektem bliskiej współpracy M. Jaczynowskiej z badaczami francuskimi skupionymi wokół prestiżowego czasopisma L’année épigra- 
phique. Oczywiście nie oznacza to, że inne elementy narracji konieczne do przedstawienia pełnego obrazu dziejów starożytnego Rzymu, zostały potraktowane przez autorkę skrótowo. Układ omawianego podręcznika był prawie identyczny jak skryptu toruńskiego. Zgodnie jednak z deklaracją autorki wiele zagadnień zostało omówionych znacznie dokładniej.

W swych podręcznikach M. Jaczynowska wiele miejsca poświęcała pierwotnej religii rzymskiej i jej późniejszym przeobrażeniom. Niewątpliwie było to konsekwencją jej wcześniejszych zainteresowań naukowych, a po latach doprowadziło do publikacji osobnej monografii poświęconej religiom rzymskim. Ukazała się ona w 1987 roku pod tytułem Religie świata rzymskiego ${ }^{9}$. Z formalnego punktu widzenia był to również podręcznik adresowany przede wszystkim do studentów, co autorka podkreśliła we wstępie. Jego założeniem było „ukazanie przemian religijnych w okresie rozkwitu Imperium Rzymskiego, a więc poczynając od III wieku p.n.e. do III w. n.e.".

Jak już wcześniej zaznaczaliśmy, w 1995 roku Maria Jaczynowska opublikowała w Wydawnictwie Naukowym PWN nowatorski podręcznik zatytułowany Dzieje Imperium Romanum. Od publikowanych wcześniej przez nią podręczników ten różnił się zarówno formą, jak i treścią. Autorka zrezygnowała z przedstawiania całości dziejów Rzymu, a skoncentrowała się na dziejach rzymskich podbojów, tworzeniu potężnego imperium, a następnie na walce o jego utrzymanie. W narracji nie zostały omówione początki Rzymu ani dzieje Rzymu w okresie królewskim. We wstępie co prawda został skrótowo omówiony podbój Italii przez Rzym, ale właściwym punktem wyjścia był dla autorki początek podbojów poza Italią, a zatem 264 rok p.n.e. Koncentracja na podbojach nie oznacza, że w podręczniku pominięto inne ważne kwestie. Odpowiednie rozdziały zostały poświęcone przemianom społecznym, politycznym, gospodarczym, kulturowym i religijnym, będącym efektem rozszerzenia granic imperium i włączania do niego nowych społeczności. Wiele miejsca autorka poświęciła wyjaśnianiu, dlaczego Rzymianom udało się podbić cały basen Morza Śródziemnego.

${ }^{9}$ D. Musiał, A. Gillmeister, Badania nad religia rzymska w Polsce, [w:] Oblicza starożytności. Z badań nad historia starożytna w Polsce, red. M. Wolny, Olsztyn 2012, s. 108-112 . 
Szczegółowo omówiła zatem zagadnienia związane z wojskowością rzymską, ale również specyficzną umiejętność elit republiki rzymskiej wzbudzania społecznego zainteresowania dalszymi podbojami. Wielokrotnie zwracała uwagę, że Rzym utrzymał swe panowanie i był w stanie zapewnić spokój wewnętrzny nie tylko siłą. Podkreślała atrakcyjność przynależności do Imperium Romanum - podbite ludy mogły zachowywać autonomię oraz odrębność kulturową, ale jednocześnie zyskały możliwość należenia do większej wspólnoty.

We wstępie do omawianego podręcznika M. Jaczynowska deklarowała, że jej celem jest nie tylko przedstawienie procesów, które doprowadziły do stworzenia przez Rzym imperium, ale również walki o jego przetrwanie w okresie późnego cesarstwa rzymskiego. Pisała m.in. „późnemu cesarstwu poświęcono w tej książce niewspółmiernie więcej uwagi niż okresom wcześniejszym". Ostatnia część podręcznika liczy ponad 150 stron i jest bardzo szczegółowym opisem okresu od 284 do 476 roku. Fakt ten zasługuje na podkreślenie, ponieważ przed ukazaniem się Dziejów Imperium Romanum nie było w Polsce pracy, w której aż tyle miejsca poświęcono by na omówienie najróżniejszych zjawisk z tego okresu. Można nawet zaryzykować twierdzenie, że publikacja omawianego podręcznika w jakimś stopniu mogła przyczynić się do niebywałego rozkwitu w Polsce badań nad późnym antykiem. Maria Jaczynowska omówiła nie tylko historię polityczną, społeczną i kulturową późnej starożytności. Wiele miejsca poświęciła na przybliżenie jakże niezbędnych informacji na temat źródeł do historii późnego cesarstwa oraz podstawowych opracowań zagranicznych i polskich.

Wcześniej wspomniano, że podręcznikowym debiutem M. Jaczynowskiej był praca napisana wspólnie z A. Mączakową i W. Tylochem. Po latach M. Jaczynowska powróciła do podobnej formuły jednotomowego podręcznika obejmującego całą starożytność. W 1999 roku w wydawnictwie „Trio” ukazała się przygotowana pod redakcją M. Jaczynowskiej praca zatytułowana Historia Starożytna, której współautorami byli D. Musiał (Grecja) oraz M. Stępień (Wschód). O słuszności powrotu do koncepcji jednotomowego podręcznika do starożytności najlepiej świadczy popularność, jaką omawiany podręcznik cieszył się i nadal się cieszy wśród studentów (którzy, jak pisaliśmy, kolokwialnie określają go mianem „trojaczków”). Jak dotąd Historia Starożytna miała osiem wydań i osiągnęła łączny nakład się- 
gający ponad 20 tys. egzemplarzy. Maria Jaczynowska opracowała w nim prawie 280-stronnicowy rozdział dotyczący starożytnego Rzymu. Układ tego rozdziału nie odbiegał od układu sprawdzonego już we wcześniejszych publikacjach autorki.

Na przełomie 2006 i 2007 roku M. Jaczynowska pracowała intensywnie nad kolejnym podręcznikiem, który tym razem miał być poświęcony jedynie dziejom Rzymu. Do współpracy zaprosiła M. Pawlaka. Maszynopis podręcznika został złożony w wydawnictwie we wrześniu 2007 i został opublikowany w 2008 roku, kilka miesięcy po śmierci M. Jaczynowskiej. Podręcznik zatytułowany Starożytny Rzym składa się z siedmiu części, a narracja zaczynająca się na Rzymie królewskim jest doprowadzona do śmierci Justyniana Wielkiego (565 roku). Podręcznik adresowany był do „studentów różnych kierunków nauk humanistycznych, głównie historii, filologii klasycznej, archeologii śródziemnomorskiej, częściowo także dla studiujących historię sztuki i prawo rzymskie". Autorka wyrażała nadzieję „że książka trafi także do szerokiego grona miłośników dziejów starożytnych, stanowiąc antidotum na różne konflikty współczesnego świata i dominację techniki”. We wstępie M. Jaczynowska pokusiła się o bardzo interesujący fragment dotyczący jej doświadczeń w zakresie pisania podręcznika historii starożytnego Rzymu. W tym swoistym credo doświadczonego autora podręczników znalazła się i taka ważna uwaga „Oddana pod koniec 2007 roku do druku książka Starożytny Rzym stanowi w skróconej postaci podsumowanie moich doświadczeń w zakresie pisania podręczników dla studentów, uzupełnione w miarę możliwości współczesną wiedzą z zakresu historii Rzymu”.

Maria Jaczynowska pisała i publikowała podręczniki przez blisko 40 lat. Cieszyły się one i cieszą nadal niesłabnącą popularnością wśród studentów. Wielka w tym zasługa niepowtarzalnego stylu pisarskiego autorki oraz umiejętności przedstawiania w przystępny sposób najbardziej nawet spornych i niejasnych zagadnień z dziejów antycznego Rzymu. Nie można jednak zapominać o jej pracowitości, systematyczności i konsekwencji, które konieczne są przy pisaniu każdej książki, nie tylko podręcznika. Trzeba również podkreślić dociekliwość badawczą M. Jaczynowskiej, co mógł zaobserwować M. Pawlak, asystując przy przygotowywaniu ostatniego z podręczników. Najbardziej uderzała uwaga, z jaką Profesor Jaczynowska śledziła 
wszelkie nowości wydawnicze, zarówno polskie, jak i zagraniczne. Dzięki temu była ona zawsze dobrze zorientowana w aktualnych dyskusjach naukowych, a każdy z jej kolejnych podręczników był zgodny z bieżącym stanem wiedzy.

Maria Jaczynowska pozostawała aktywna naukowo praktycznie do ostatnich dni. We wrześniu 2007 roku była gościem konferencji naukowej zorganizowanej w Toruniu przez Sekcję Historii Starożytnej PTH poświęconej społeczeństwu i religii w świecie starożytnym. Odeszła 21 lutego 2008 roku, wkrótce po osiemdziesiątych urodzinach, na które zaprosiła Rodzinę oraz swoich Uczniów i Współpracowników z Zakładu.

Professor Maria JaczynowsKa - THE EMINENT Historian OF ANCIENT WORLD

(SUMMARY)

The article is a profile of Professor Maria Jaczynowska (1928-2008), one of the most outstanding Polish historians of Antiquity. It includes an outline of the personal and academic life of the Professor and a more in-depth analysis of her achievements in the field of epigraphic research. It also presents her as an author of academic textbooks, which were very popular with students for many decades. Professor Jaczynowska, who graduated from the University of Warsaw, was associated with the Nicolaus Copernicus University in Torun for most of her professional life. It was here that she built, from the ground up, the Department of Ancient History in the Institute of History and Archival Sciences. Her research interests were varied and included such problems as the social history of the Roman Republic and the early Empire, organisations gathering Roman youths, and Roman religions. Many of her articles were published in the most prestigious European history magazines. Les associations de la jeunesse romaine sous le Haut-Empire (1978), Le culte de l'Hercule romain au temps du Haut-Empire, 
ANRW II 17. 1 (1981), and Religie świata rzymskiego $(1987,1990)$ are among her most quoted works. The article was written for the sixth anniversary of Professor Jaczynowska's death.

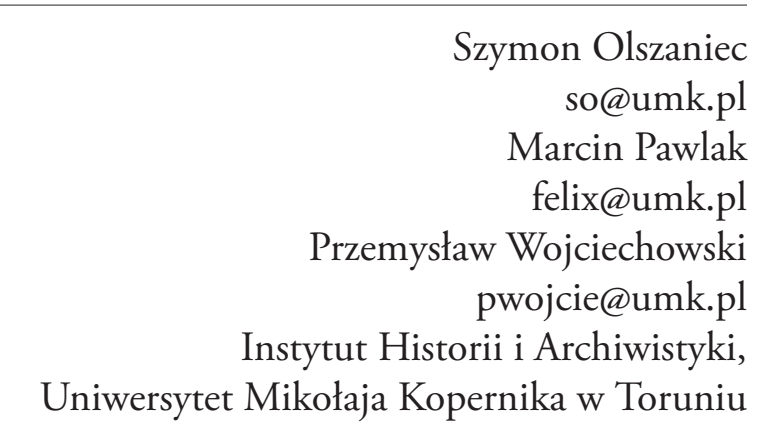

